\title{
MONETARY POLICY AND INDUSTRIAL OUTPUT IN THE BRICS COUNTRIES: A MARKOV-SWITCHING MODEL
}

\author{
Adebayo Augustine Kutu, M.Com (Econ.) \\ Harold Ngalawa, Ph.D. ${ }^{2}$ \\ University of KwaZulu-Natal \\ School of Accounting, Economics \& Finance \\ Westville Campus, Republic of South Africa \\ 1e-mail:kutuA@ukzn.ac.za \\ ${ }^{2}$ e-mail:ngalawa@ukzn.ac.za
}

Received 16 May 2017, Accepted 8 October 2017

\begin{abstract}
This paper examines whether the five BRICS countries share similar business cycles and determines the probability of any of the countries moving from a contractionary regime to an expansionary regime. The study further examines the extent to which changes in monetary policy affect industrial output in expansions relative to contractions. Employing the Peersman and Smets (2001) Markov-Switching Model (MSM) and monthly data from 1994.01-2013.12, the study reveals that the five BRICS countries have similar business cycles. The results further demonstrate that the BRICS countries' business cycles are characterized by two distinct growth rate phases: a contractionary regime and an expansionary regime. It can also be observed that the area-wide monetary policy has significantly large effects on industrial output in recessions as well as in booms. It has also been established that there is a high probability of moving from state one (recession) to state two (expansion) and that on average, the probabilities of staying in state 2 (expansion) are high for each of the five countries. It is, therefore, recommended that the BRICS countries should sustain uniform policy consistency (monetary policy), especially as they formulate and implement economic policies to stimulate industrial output.
\end{abstract}

Keywords: monetary policy, industrial output, BRICS countries, Markov-Switching Model

JEL classification: E52, L25, C01, C02 


\section{Introduction}

One of the characteristics of any economy is the recurrence of business cycles. This term refers to the pattern of expansion and contraction in economic activity about the path of trend growth in the economy (Harding, Pagan, 2002). Long periods of expansion may create the impression that business cycles are a phenomenon of the past but experience teaches us that recessions are inevitable. According to Caraiani (2010), recessions are most likely necessary periods of restructuring and reform, when boom misallocations are corrected. However, the way monetary policy affects economic activities (especially in the correctional process) has received increased attention in the literature through the analysis of business cycles (see Casares, 2001; Kim, 2003; Korenok, Radchenko, 2004). Policymakers and academics alike have sought to understand the fundamental causal relationships between monetary policy actions and business cycles. For example, several studies have argued that monetary policy has more significant effects on output in a recession than in a boom (see Peersman, Smets, 2001; Peersman, Smets, 2005) and can foster economic growth in the short run (see Adejare, 2014). Huber and Fischer (2015) concur and state that the effects of monetary policy are stronger in recessions, whereas the responses are more muted in the medium and long-term expansionary phases of the business cycles due to the price effect.

In contrast, Tenreyro and Thwaites (2015) found strong evidence that the effects of monetary policy on real and nominal variables are more powerful in expansions than in recessions. However, Garcia and Schaller (2002) have shown that an expansionary monetary policy (reduction in interest rates) will lower output in both a recession and an expansion. In view of these divergent views, this study seeks to examine the effects of changes in monetary policy in booms versus recessions on industrial output in Brazil, Russia, India, China and South Africa, a group of emerging market economies (EMEs), generally referred to as the BRICS.

To the best of the researchers' knowledge, this is the first study to jointly estimate and compare the effects of changes in monetary policy in booms versus recessions on industrial output in the BRICS countries. In addition, no study has jointly determined the probability of moving from one regime (recession) to the other (expansion/boom) as well as establishing how long, on average, a particular regime will last. Therefore, this study provides an up-todate analysis of the nexus among the effects of monetary policy and industrial output in booms versus recessions in the BRICS economies.

Various shifts in the conduct of monetary policy have occurred in the BRICS countries over the past four decades. Although these have taken diverse forms, the shifts have been towards 
more systematic rules and less discretion in the conduct and implementation of monetary policy. Some countries, including Brazil, India and South Africa, have officially adopted inflation targeting. Hutchison et al. (2013) have shown that other EMEs (including Russia and China) have adopted systematic rules that de facto define the conduct of the central bank's operating instrument using interbank interest rates. They have also highlighted official commitment to complete the shift towards a floating exchange rate system and inflation-targeting regime. Rose (2007) contends that the adoption of systemic rules focusing on inflation or the shift towards inflation targeting regimes, either implicitly or explicitly, has generated a new monetary system that is more stable than those previously adopted such as the fixed exchange rates system and exchange rate targeting.

For a central bank to direct the economy towards a more sustainable growth path, it is important to understand the fundamental behaviour of business cycles. This is based on the assumption that policymakers will discern where the economy is located and more importantly, where it is heading in order to deal with possibly adverse future economic events. When the economy has reached or is heading in an undesirable direction, economists or policymakers may apply monetary policy tools to redirect its course. Economic indicators such as GDP (in particular, industrial output) and the inflation rate are indicators of business cycles.

Theoretical studies have developed optimal monetary policy rules, and empirical studies have investigated uncertainty as a potential driver of business cycles (see Taylor, 1993; Faia, 2008; Binici, Erol, Özlü, Ünalmış, 2013; Fendoğlu, 2014; Grimme, 2015; Chuliá, Guillén, Uribe, 2015). Taylor's (1993) optimum monetary policy rule is formulated on the premise that the United States (US) Federal Reserve Bank adjusts the policy rate in response to past inflation and the output gap (actual minus potential output). He showed that this rule described the Bank's policy and how it performed from 1987 to 1992. Using a sticky price Dynamic Stochastic General Equilibrium (DSGE) model, Faia (2008) provides formal justification for following a Taylor-type rule in which the optimal monetary policy design is based on both constrained and global Ramsey policies. Many studies have subsequently applied the Taylortype optimal monetary policy rule to study business cycles and examine the behaviour of central banks in industrialized countries (see Clarida, Gali, Gertler, 2001; Lin, Ye, 2007), while several others have applied the same approach to EMEs (see Gonçalves, Salles, 2008; Lin, Ye, 2009). Gonçalves and Salles (2008) survey of 36 EMEs found that the 13 countries that have adopted inflation targeting experienced low inflation and a greater decline in growth volatility, which helped to smoothen and stabilize their business cycles. 


\section{Objectives of the Study}

Given the foregoing context, this study investigates whether the BRICS countries share similar business cycles. This is achieved with the following four broad objectives:

- to investigate monetary policy regime changes in the BRICS countries,

- to determine the effects of changes in monetary policy during booms versus recessions on industrial output in the BRICS countries,

- to determine the probability of moving from one monetary policy regime to the other,

- to determine how long, on average, a regime will last given that an economy of any of the BRICS countries is in regime 1 (recession) or regime 2 (boom).

\section{The Theory of Business Cycles}

This study is rooted in the pure monetary theory due to its optimum rule that best fits Taylor's (1993) optimum monetary policy rule that was adopted in this study to explain the BRICS economies' business cycles. The theory takes into consideration the monetary and credit system of an economy to analyse business cycles because the literature has identified the credit channel as one of the transmission mechanisms through which monetary authorities drive economic growth (see Mishkin, 1995; Zhensheng, 2002). Hawtrey (1927) propounded this theory in 1927 where he postulated that changes in money flows in an economy cause fluctuations in the level of economic activities. Thus, the theory posits that business cycles are a consequence of fluctuations in the monetary and credit markets as credit expansion helps to expand economies. Another reason for the adoption of this theory is that Hawtrey (1927) employed trade cycles to explain that business cycles are a purely monetary phenomenon because aggregate demand is itself a monetary phenomenon and credit greases the economy to stimulate growth (Kelly, O'Malley, 2014). This is in line with the BRICS countries' agenda of partnering for trade, integration and industrialization (see Chun, 2014) in order to achieve economic growth.

Fluctuations in bank credit and the supply of money are the main causes of business cycles (Schularick, Taylor, 2012). Following an increase in money supply, price rises, total output and profits increase, and the economy enters an expansion phase, at least in the short run. On the other hand, if the supply of money falls, prices also fall, profits decline, total output falls as industrial production becomes sluggish, and the economy enters a contractionary phase.

The principle factor behind money supply is credit created by the banking system. The economy discerns the upswing with the expansion of bank credit and continues to expand 
as long as the banks create credit. The banks expand the credit facility because they find it profitable to offer credit at a relatively lower interest rate since the risk of default is relatively lower at such rates. This encourages entrepreneurs to undertake productive activities and enjoy the benefits of bank credit.

As the process of credit expansion continues, the general price level increases and after reaching a certain limit, the rate of increase in aggregate demand exceeds the increase in aggregate supply. Aggregate supply increases at a lower rate because of limited production capacity and the gestation period of new investments. Consequently, credit expansion helps to accelerate the economy while at the same time putting upward pressure on prices.

Finally, at some point, the banks might restrain credit expansion at the prevailing rate because their cash and reserves are depleted due to the increase in loans and advances, withdrawal of deposits for quicker returns and reduced inflow of deposits, among others. With the contraction of credit, businesses can no longer obtain bank credit to expand their business activities. Expansion slows, marking the beginning of a downswing. These processes of money supply and credit creation provide an understanding of the fundamental behaviour of a business cycle in the economy.

\section{Methodology}

To achieve the stated objectives, this study employs the Markov-Switching Model (MSM) for each country $i$, out of $n$ countries (five BRICS countries). The MSM is a model of asset returns that incorporates stochastic volatility or variation components of heterogeneous durations. It captures the effects of switching from one regime (recession) to another (expansion) over time. The model compares favourably with standard volatility (shock) models such as GARCH $(1,1)$, EGARCH and APARCH as well as VAR and SVAR.

The MSM is employed in this study because it has several advantages. First, the model is able to capture the effects of monetary policy on industrial output in the five BRICS countries under consideration as employed by Peersman and Smets (2001) for the seven Euro area countries. Second, compared to the VAR approach used in Dedola and Lippi (2000) and Hayo and Uhlenbrock (2000), the MSM is superior because of its specification simplicity that allows for changes in mean and variance. In addition, the model is able to test the probabilities of being in a recession or an expansion or whether monetary policy has stronger effects on industrial output in recessions than in expansions (see Garcia, Schaller, 2002). This means that the MSM approach makes it easy to distinguish between business cycle phases (Medhioub, 2015). 
Furthermore, the MSM can allow for multiple breaks and can detect outliers in time series data (Hamilton, 1989).

MSM also allows us to analyse the effects of BRICS countries' changes in monetary policy in booms versus recessions on industrial output. This study considers this approach suitable not only because it resembles the various policy regime shifts in the BRICS countries' fiscal and monetary policies, but also because the fiscal and monetary policies in these countries are well coordinated through participation and consultations in various annual summits that include the meetings of heads of state, finance ministers, national security advisers, agricultural, trade and industry, foreign affairs and health ministers, science and technology senior officials, BRICS competition experts, and businessmen generally, among others.

Suppose that the MSM for the BRICS countries is given as:

$$
\Delta y_{i, t}-\mu_{i, s_{t}}=\varnothing_{1}\left(\Delta y_{i, t-1}-\mu_{i, s_{t-1}}\right)+\varnothing_{2}\left(\Delta y_{i, t-2}-\mu_{i, s_{t-2}}\right)+\varepsilon_{i, t}
$$

where:

$$
\left[\begin{array}{c}
\varepsilon_{1, t} \\
\vdots \\
\varepsilon_{n, t}
\end{array}\right] \sim \text { i.id. } N\left(\left[\begin{array}{c}
0 \\
\vdots \\
0
\end{array}\right],\left[\begin{array}{ccc}
\sigma_{11} & \cdots & \sigma_{1 n} \\
\vdots & \ddots & \vdots \\
\sigma_{1 n} & \cdots & \sigma_{n n}
\end{array}\right]\right)=N(0, \Omega)
$$

$\Delta y_{i, t}$ is the monthly industrial output in each country $i ; \mu_{i, s_{t}}$ is the mean growth rate conditional on country $i$ being in state $s_{t}$. In this model, we assume that the state of the economy is identical in each of the $n$ countries. Following Hamilton (1989), we assume that the autoregressive parameters $\left(\varnothing_{1}, \varnothing_{2}\right)$ are independent of the state or regime and the country. $s_{t}$ is assumed to follow a two state Markov chain with the following transition probability matrix:

$$
P=\left[\begin{array}{cc}
P_{00} & P_{01} \\
P_{10} & P_{11}
\end{array}\right]
$$

where $P_{00}$ is the probability that the series is at state 0 (recession) at time $\mathrm{t}$ and remains at state 0 at time $t+1, P_{01}$ is the probability that the series is at state 0 at time $\mathrm{t}$ and transitions to state 1 (expansion or boom) at time $t+1, P_{10}$ is the probability that the series is at state 1 at time $\mathrm{t}$ and transitions to state 0 at time $t+1$, and $P_{11}$ is the probability that the series is at state 1 at time $t$ and remains in state 1 at time $t+1$. Formula 3 can further be described by:

$$
P_{i j}=\operatorname{Pr}\left[s_{t+1}=j \mid s_{t}=i\right] \text { with } \sum_{j=0}^{1} P_{i j}=1 \text { for all } i
$$


Formula 4 shows the probability of transitioning (moving) from state $j$ to state $i$. Following Peersman and Smets (2001), we assume that these transition probabilities are constant over time and take the following logistic form:

$$
\begin{gathered}
P_{00}=\operatorname{Pr}\left[s_{t+1}=0 \mid \quad s_{t}=0\right]=\frac{\exp \left(\varnothing_{0}\right)}{1+\exp \left(\varnothing_{0}\right)} \\
P_{11}=\operatorname{Pr}\left[s_{t+1}=1 \mid s_{t}=1\right]=\frac{\exp \left(\varnothing_{1}\right)}{1+\exp \left(\varnothing_{1}\right)}
\end{gathered}
$$

Formula 5 is the probability that the series is at state 0 (recession) at time $s_{t}$ and remains at state 0 at time $s_{t+1}$ while formula 6 is the probability that the series is at state 1 (expansion or boom) at time $s_{t}$ and remains in state 1 at time $s_{t+1}$. We define $Y_{t}=\left[\Delta y_{1, t}, \Delta y_{2, t}, \ldots, \Delta y_{n, t}\right]$, as a vector of observations on output growth (see Peersman, Smets, 2001). This model implies that the conditional density function takes the form:

$$
f\left(Y_{t} \mid Y_{t-1}, \ldots, Y_{1}, s_{t}\right)=(2 \pi)^{-1}|\Omega|^{-\frac{1}{2}} \exp \left[-\frac{1}{2}\left(Y_{t}-h_{t, s_{t}}\right)^{\prime} \Omega^{-1}\left(Y_{t}-h_{t, s_{t}}\right)\right]
$$

where:

$$
h_{t, s_{t}}=\left[\begin{array}{c}
\mu_{1, s_{t}}-\varnothing_{1} \mu_{1, s_{t-1}}-\varnothing_{2} \mu_{1, s_{t-2}}+\varnothing_{1} \Delta y_{1, t-1}+\varnothing_{2} \Delta y_{1, t-2} \\
\mu_{n, s_{t}}-\varnothing_{1} \mu_{n, s_{t-1}}-\varnothing_{2} \mu_{n, s_{t-2}}+\varnothing_{1} \Delta y_{n, t-1}+\varnothing_{2} \Delta y_{n, t-2}
\end{array}\right]
$$

Formulas 7 and 8 are transitional matrices $\left(\varnothing_{1}\right.$ and $\varnothing_{2}$ are parameters $)$ as given in the conditional density function (see Peersman, Smets, 2001, 2005) where we also obtain a sequence of conditional probabilities $\operatorname{Pr}\left(s_{t}=i \ldots s_{t+r}=j \mid \varnothing_{t}\right)$, which are the probabilities that the series is in state $i$ or $j$ at times $t, t+1$, until $t+r$ respectively, conditional upon the information available at time $t . \Omega$ denotes series capturing the denominators for formulas 5 and 6 in state $i$ or $j$ at times $t, t+1$. By summing these joint probabilities, we can obtain the filtered probabilities, which are the probabilities of being in state 0 or 1 at time $t$, given the information available at time $t$ as:

$$
\operatorname{Pr}\left(s_{t}=j \mid \varnothing_{t}\right)=\sum_{i=0}^{1} \ldots \ldots \sum_{k=0}^{1} \operatorname{Pr}\left(s_{t}=j, s_{t+1}=i, \ldots s_{t+r}=k \mid \varnothing_{t}\right) j, i, \ldots \ldots k=0,1
$$

These probabilities in formula 9 provide information about the regime in which the series is most likely to have been at every point in the sample (constant expected duration). 


\section{Does monetary policy change the likelihood of an expansion during a recession?}

Following Garcia and Schaller (1995, 2002) and Dolado and Maria-Dolores (1999), this study assesses the transition probabilities of moving from one state to the other (from recession to expansion). The transition probabilities are given as follows:

$$
\begin{gathered}
P_{00}=\operatorname{Pr}\left[s_{t+1}=0 \mid s_{t}=0\right]=\frac{\exp \left(\varnothing_{00}+\varnothing_{01} M P_{t}\right)}{1+\exp \left(\varnothing_{00}+\varnothing_{01} M P_{t}\right)} \\
P_{11}=\operatorname{Pr}\left[s_{t+1}=1 \mid s_{t}=1\right]=\frac{\exp \left(\varnothing_{10}+\varnothing_{11} M P_{t}\right)}{1+\exp \left(\varnothing_{10}+\varnothing_{11} M P_{t}\right)}
\end{gathered}
$$

In order to isolate the effect of monetary policy on the transition probabilities from the linear effect examined above, we constrain the coefficients to be equal to zero as in formula 1. Based on formulas 10 and 11 , we would expect $\varnothing_{00}$ to be the probability of staying in a recession, and $\emptyset_{01}$ to explain the probability of moving from recession to boom. In contrast, $\varnothing_{10}$ shows the probability of moving from a boom to a recession and $\varnothing_{11}$ is the probability of staying in an expansion (boom). $M P_{t}$ is the monetary policy indicator in recession or an expansion.

\section{How long on average will this regime last?}

In order to develop the industrial output effects of monetary policy in the BRICS countries in booms (expansions) versus recessions, this study follows Peersman and Smets (2005) to estimate for each country $i$ using the linear MSM regression equation given as:

$$
\begin{aligned}
& \Delta y_{i t}=\left(\alpha_{i, o} p_{o, t}+\alpha_{i, 1} p_{1, t}\right)+\varnothing_{i, 1} \Delta y_{i, t-1}+\varnothing_{i, 2} \Delta y_{i, t-2}+ \\
+ & \left(1-\varnothing_{i, 1}-\varnothing_{i, 2}\right)\left(\beta_{i, o} p_{o, t-1} M P_{t-1}+\beta_{i, 1} p_{1, t-1} M P_{t-1}\right)+\varepsilon_{i, t}
\end{aligned}
$$

where $\Delta y_{i, t}$ is the monthly growth rate of industrial output of BRICS member country $i, M P_{t}$ represents monetary policy indicators (interest rates and money supply) and $p_{o, t}$, and $p_{1, t}$ are probabilities of being in a recession or an expansion at a given time $t\left(p_{o, t}+p_{1, t}=1\right)$. Formula 12 is a reduced-form Markov-Switching output formulation that is estimated in this study in line with Peersman and Smets (2001).

\subsection{Definition of variables, data and data sources}

Industrial output (IP) is the contribution of the industrial sector's output to GDP. This is used to examine how monetary policy affects industrial sector performance in the BRICS 
countries as the sector provides a locus to stimulate the growth of the economy. In this study, the role industry plays in stimulating the economy is further elaborated in line with Elbourne and De Haan (2006). Money supply (MS) is the entire stock of currency and other liquid instruments in each country at a particular time. $M 2$ is employed in this study in line with Ngalawa and Viegi (2011) for all the BRICS countries except India where $M 3$ is used due to the non-availability of M2. Interest rate (IN) is the real repo rate set by the central bank of each individual country as a monetary policy indicator (see Disyatat, Vongsinsirikul, 2003; Iturriaga, 2000) and will enable us to assess the process through which it is used to counter inflation and manage the movement of intermediate targets of monetary policy. All data are monthly time series covering a period of 20 years from 1994.01 to 2013.12 for the five BRICS countries. The study period and cutoff dates are dictated by data availability and the data are obtained from each country's Central Bank's statistical bulletins and Statistics Offices.

\subsection{Estimation Results}

Following Schaller and Norden (1997), Hardy (2001), Alvarez-Plata and Schrooten (2006) and Sims and Zha (2006) we estimated monetary policy shocks in a multivariate MSM using monthly data from 1994-2013 for each of the BRICS countries, in order to determine whether the BRICS countries shared similar business cycles. The use of monthly frequency data for the estimation has the advantage of allowing for higher degrees of freedom that enables better estimates for each country.

As is shown in Figure 1, the MSM reveals that the BRICS countries have similar business cycles. The results demonstrate that these countries' business cycles are characterized by two distinct growth rate phases: a recession regime and an expansion growth rate regime as opposed to some countries with three growth rate phases: a recession regime, a moderate growth regime and a high growth regime (see Medhioub, 2015).

It can be observed that economic activity, which shifts from one process to another, is governed by the "latent state of two regimes". The trends in Figure 1 show that the business cycles in BRICS countries are common and similar. They can be traced from a recession to a trough before the economy picks up in an expansionary phase (and verse versa). These results are similar to Hutchison et al.'s (2013) finding that the conduct of monetary policy over business cycles can be characterized by two regimes.

Based on the second objective of this paper, the study further employs the MSM to determine the probability of moving from one regime to the other and how long, on average, each regime will last. 

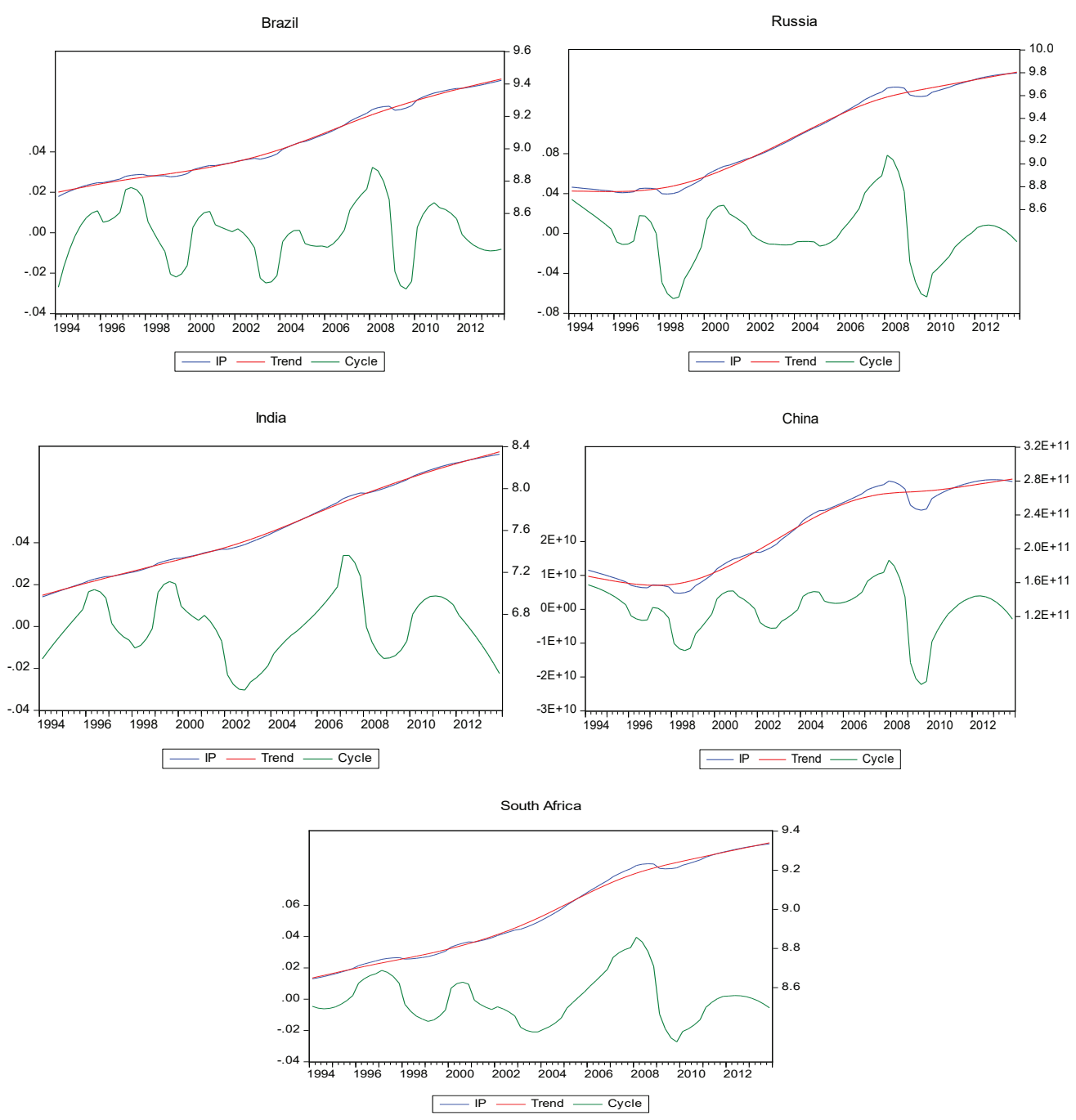

Figure 1. Cycles in BRICS Countries

Source: author's computations using data from each country's Central Bank's statistical bulletins and Statistics Offices.

\subsection{Results for Brazil}

Table 1 provides estimates for the Brazilian economy. This study reports the probabilities of being in regime 1 (recession) or shifting to regime 2 (expansion or boom). A change in monetary policy using interest rates and money supply significantly affects industrial output as shown by the statistically significant coefficients. This indicates that the countrywide monetary policy has effects on industrial output both in a recession and in a boom. Using the log (sigma), 
the value of 22.0675 shows that the economy is less likely to be in regime 1 (recession) than regime 2 (expansion/boom) as shown by the coefficient value of 22.5168 . This result indicates that the likelihood of being in a boom or expansion is higher than the likelihood of being in a recession. In addition, Table 2 shows the transition probabilities of staying in a recession or an expansion. Based on these results, the probability value of 0.9158 is less than 0.9806 , indicating that the probability of an economy staying in a recession is less than that of being in an expansion. The results, therefore, reveal that the economy stays more in a boom than it does in a recession in Brazil. This is further confirmed by the constant expected duration given in Table 3. The table reveals that the total expected duration of staying in a recession is 11 months while that of staying in an expansion is 51 months. There is a high probability of transitioning from a recession to an expansion as shown by the probability value of 0.0194 in regime $2_{(t)}$ and the probability value of 0.0842 in regime $2_{(t+2)}$ (see Table 2 ).

Table 1. Regime Shifts in Brazil

\begin{tabular}{|l|c|c|c|c|}
\hline \multicolumn{1}{|c|}{ Variable } & Coefficient & Std. error & Z-Statistic & Prob. \\
\hline \multicolumn{5}{|c|}{ Regime 1 } \\
\hline IN & 9.2813 & 3.5321 & 2.4987 & 0.0125 \\
\hline MS & 0.0477 & 0.0006 & 78.6374 & 0.0000 \\
\hline C & 1.7814 & 7.8237 & 227.2339 & 0.0000 \\
\hline LOG(SIGMA) & 22.0675 & 0.0651 & 339.1598 & 0.0000 \\
\hline \multicolumn{5}{|l|}{ Regime 2 } \\
\hline IN & 4.7477 & 1.5161 & 3.145076 & 0.0017 \\
\hline MS & 0.0526 & 0.001989 & 26.45551 & 0.0000 \\
\hline C & 1.8828 & 2.6049 & 72.35967 & 0.0000 \\
\hline LOG(SIGMA) & 22.5168 & 0.0814 & 276.5452 & 0.0000 \\
\hline \multicolumn{5}{|l|}{ Transition Matrix Parameters } \\
\hline P11-C & 3.9255 & 0.5948 & 6.5998 & 0.0000 \\
\hline P21-C & -3.0754 & 0.5055 & -6.0840 & 0.0000 \\
\hline
\end{tabular}

Source: author's computations using data from each country's Central Bank's statistical bulletins and Statistics Offices.

Table 2. Transition probabilities

\begin{tabular}{|l|c|c|}
\cline { 2 - 3 } \multicolumn{1}{c|}{} & Regime $1_{(t+1)}$ & Regime $2(t+2)$ \\
\hline Regime $1_{(t)}$ & 0.9158 & 0.0842 \\
\hline Regime $2_{(t)}$ & 0.0194 & 0.9806 \\
\hline
\end{tabular}

Source: author's computations using data from each country's Central Bank's statistical bulletins and Statistics Offices. 
Table 3. Constant expected durations

\begin{tabular}{|c|c|}
\hline Regime 1 & Regime 2 \\
\hline 11.8746 & 51.5396 \\
\hline
\end{tabular}

Source: author's computations using data from each country's Central Bank's statistical bulletins and Statistics Offices.

\subsection{Results for Russia}

Parameter estimates for the Russian economy are presented in Table 4. The results describe the effects of a Russian monetary policy shock on industrial output in the country. There is a high possibility of being in regime 2 given the value of 22.8175 as against the possibility of being in regime 1 with the value of 22.0856. This result is similar to that of Brazil where it was found that the likelihood of being in a boom or an expansion is higher than the likelihood of being in a recession. The high likelihood of transitioning from a recession to an expansion is shown by the probability value of 0.0068 in regime $2_{(t)}$ and the probability value of 0.0554 in regime $2_{(t+2)}$. Further justification for this is the result derived in table 5 where the transition probability of staying in a recession is less than that of staying in an expansion. Given these results, the probability value of 0.9446 of staying in a recession is less than the probability value of 0.9932 of staying in an expansion. This result reveals that the Russian economy is more likely to be in a boom than in a recession. The expected duration is shown in Table 6 . The table reveals that the total expected duration of staying in a recession is 18 months while that of staying in an expansion is 146 months.

Table 4. Regime Shifts in Russia

\begin{tabular}{|l|r|r|r|r|}
\hline \multicolumn{1}{|c|}{ Variable } & Coefficient & Std. error & Z-Statistic & Prob. \\
\hline \multicolumn{5}{|c|}{ Regime 1 } \\
\hline IN & -4.5218 & 2.9044 & -15.6104 & 0.0000 \\
\hline MS & 0.0045 & 0.0001 & 36.2767 & 0.0000 \\
\hline C & 2.4718 & 2.0567 & 120.6685 & 0.0000 \\
\hline LOG(SIGMA) & 22.0856 & 0.0987 & 223.8047 & 0.0000 \\
\hline \multicolumn{5}{|l|}{ Regime 2 } \\
\hline IN & -5.7714 & 2.6292 & -22.0377 & 0.0000 \\
\hline MS & 0.0033 & 8.8600 & 37.1597 & 0.0000 \\
\hline C & 2.1611 & 2.2815 & 94.9886 & 0.0000 \\
\hline LOG(SIGMA) & 22.8175 & 0.0580 & 393.3038 & 0.0000 \\
\hline \multicolumn{5}{|l|}{ Transition Matrix Parameters } \\
\hline P11-C & 2.8368 & 0.5205 & 5.4504 & 0.0000 \\
\hline P21-C & -4.9777 & 0.9216 & -5.4011 & 0.0000 \\
\hline
\end{tabular}

Source: author's computations using data from each country's Central Bank's statistical bulletins and Statistics Offices. 
Table 5. Transition probabilities in Russia

\begin{tabular}{|l|c|c|}
\cline { 2 - 3 } \multicolumn{1}{c|}{} & Regime $1_{(t+1)}$ & Regime $2_{(t+2)}$ \\
\hline Regime $1_{(t)}$ & 0.9446 & 0.0554 \\
\hline Regime $2_{(t)}$ & 0.0068 & 0.9932 \\
\hline
\end{tabular}

Source: author's computations using data from each country's Central Bank's statistical bulletins and Statistics Offices.

Table 6. Constant expected durations

\begin{tabular}{|c|c|}
\hline Regime 1 & Regime 2 \\
\hline 18.0613 & 146.1374 \\
\hline
\end{tabular}

Source: author's computations using data from each country's Central Bank's statistical bulletins and Statistics Offices.

As an oil producing country, Russia is prone to global shocks and may stay more in a recession than Brazil. Oil prices are determined at the global market. On the other hand, the country may stay more in an expansion because it is more developed than Brazil and the economy is also well diversified. Russia is one of the largest manufacturers of military hardware (weapons of war) in the world.

\subsection{Results for India}

The results show that monetary policy in India has a significant impact on industrial production as revealed by the statistical significance of the parameter estimates shown in Table 7. The table shows that the economy is likely to be in regime 2 given the regime value of 21.7339 as against the value of 20.7977 in regime 1 . The likelihood of being in a recession is lower than the likelihood of being in a boom. Thus, there is a high possibility of switching from regime 1 to regime 2. This is further confirmed by the result derived from the transition probabilities where the economy is less likely to stay in regime 1.

In Table 8, the probability value of 0.8902 is less than the probability value of 0.9916 . This indicates that the probability of staying in a recession is less than that of staying in an expansion. This shows that the economy stays more in an expansion than in a recession in India. It is further observed that there is a high probability of transitioning from a recession to an expansion as shown by the probability value of 0.0084 in regime $2_{(t)}$ and that of 0.1098 in regime $2_{(t+2)}$. Table 9 shows the expected duration. The total expected duration of staying in a recession is 9 months while that of staying in an expansion or boom is 119 months. As a member of BRICS and as the second largest telecom producer in the world, India stays less in a recession than Brazil and Russia. The country also stays more in a boom than Brazil but slightly less than 
Russia. This finding is similar to Aradhna (2014) who confirmed the possibility of an increase in the industrial (manufacturing) share of GDP in India. Naude et al. (2013) also confirmed that the manufacturing or industrial sector's share of employment in India and China had expanded and accounted for a significant part of aggregate growth (boom).

Table 7. Regime Shifts in India

\begin{tabular}{|l|r|r|r|r|}
\hline \multicolumn{1}{|c|}{ Variable } & Coefficient & Std. error & Z-Statistic & Prob. \\
\hline \multicolumn{5}{|c|}{ Regime 1 } \\
\hline IN & -3.2842 & 3.4977 & -9.3785 & 0.0000 \\
\hline MS & 2.6939 & 2539.897 & 10.6066 & 0.0000 \\
\hline C & 3.6026 & 2.3633 & 15.2366 & 0.0000 \\
\hline LOG(SIGMA) & 20.7977 & 0.0611 & 406.2089 & 0.0000 \\
\hline \multicolumn{5}{|c|}{ Regime 2 } \\
\hline IN & -3.1481 & 1.3600 & -230.4090 & 0.0000 \\
\hline MS & 3.0275 & 317.3451 & 95.4017 & 0.0000 \\
\hline C & 3.5690 & 1.7214 & 207.0262 & 0.0000 \\
\hline LOG(SIGMA) & 21.7339 & 0.0948 & 229.1759 & 0.0000 \\
\hline \multicolumn{7}{|c|}{ Transition Matrix Parameters } \\
\hline P11-C & 3.9576 & 0.5995 & 6.6012 & 0.0000 \\
\hline P21-C & -3.7573 & 0.6825 & -5.5050 & 0.0000 \\
\hline
\end{tabular}

Source: author's computations using data from each country's Central Bank's statistical bulletins and Statistics Offices.

Table 8. Transition probabilities in India

\begin{tabular}{|l|c|c|}
\cline { 2 - 3 } \multicolumn{1}{c|}{} & Regime $1_{(t+1)}$ & Regime $2_{(t+2)}$ \\
\hline Regime $1_{(t)}$ & 0.8902 & 0.1098 \\
\hline Regime $2_{(t)}$ & 0.0084 & 0.9916 \\
\hline
\end{tabular}

Source: author's computations using data from each country's Central Bank's statistical bulletins and Statistics Offices.

Table 9. Constant expected durations

\begin{tabular}{|c|c|}
\hline Regime 1 & Regime 2 \\
\hline 9.1095 & 119.4080 \\
\hline
\end{tabular}

Source: author's computations using data from each country's Central Bank's statistical bulletins and Statistics Offices.

\subsection{Results for China}

China is the most populous country in the world with a population of 1.36 billion and is the second largest manufacturer of goods in the world after the US. Its vast resources and 
geographical location create a strong market advantage. As is shown in table 10, monetary policy in China has a significant impact on industrial production both in a recession and in a boom and there is high possibility of staying in regime 2 with a value of 24.8687 against that of 24.2218 in regime 1 . The likelihood of transitioning to and staying in regime 2 is higher than the likelihood of staying in regime 1 . This is confirmed by the result derived from the transition probabilities where it is observed that China is less likely to stay in regime 1 (see Table 11). There is a high probability of transitioning from a recession to an expansion as shown by the probability value of 0.0125 in regime $2_{(t)}$ and that of 0.2882 in regime $2_{(t+2)}$. The transition matrix also reveals the probability value of 0.9875 of staying in regime 2 as compared to that of 0.7118 of staying in regime 1 . This points to the fact that the probability of staying in a recession is less than the probability of staying in an expansion or boom in China. The total expected duration of staying in a recession in China is 3 months while the likely expected duration of staying in an expansion or boom is 80 months (see Table 12).

China has the second largest economy in the world after the US; the country is well diversified; and it remains the most industrialized among the BRICS members. Naude et al. (2013) also confirm that the manufacturing or industrial share of employment in China has expanded and accounts for a significant part of the country's aggregate growth (boom).

Table 10. Regime Shifts in China

\begin{tabular}{|l|r|r|r|r|}
\hline \multicolumn{1}{|c|}{ Variable } & Coefficient & Std. error & Z-Statistic & Prob. \\
\hline \multicolumn{5}{|c|}{ Regime 1 } \\
\hline IN & 1.3922 & 5.7618 & 24.2034 & 0.0000 \\
\hline MS & 0.0152 & 0.0003 & 47.8048 & 0.0000 \\
\hline C & 3.8357 & 1.5606 & 24.5413 & 0.0000 \\
\hline LOG(SIGMA) & 24.2218 & 0.4563 & 53.0854 & 0.0000 \\
\hline \multicolumn{5}{|l|}{ Regime 2 } \\
\hline IN & -6.1247 & 5.3601 & -11.4282 & 0.0000 \\
\hline MS & 0.0202 & 0.0004 & 57.0248 & 0.0000 \\
\hline C & 5.8600 & 2.9836 & 19.6730 & 0.0000 \\
\hline LOG(SIGMA) & 24.8687 & 0.1446 & 172.0394 & 0.0000 \\
\hline \multicolumn{5}{|l|}{ Transition Matrix Parameters } \\
\hline P11-C & 0.9041 & 0.2797 & 3.2324 & 0.0012 \\
\hline P21-C & -4.3706 & 0.7778 & -5.6190 & 0.0000 \\
\hline
\end{tabular}

Source: author's computations using data from each country's Central Bank's statistical bulletins and Statistics Offices. 
Table 11. Transition probabilities

\begin{tabular}{|l|c|c|}
\cline { 2 - 3 } \multicolumn{1}{c|}{} & Regime $1_{(t+1)}$ & Regime $2_{(t+2)}$ \\
\hline Regime $1_{(t)}$ & 0.7118 & 0.2882 \\
\hline Regime $2_{(t)}$ & 0.0125 & 0.9875 \\
\hline
\end{tabular}

Source: author's computations using data from each country's Central Bank's statistical bulletins and Statistics Offices.

Table 12. Constant expected durations in China

\begin{tabular}{|c|c|}
\hline Regime 1 & Regime 2 \\
\hline 3.4697 & 80.0911 \\
\hline
\end{tabular}

Source: author's computations using data from each country's Central Bank's statistical bulletins and Statistics Offices.

\subsection{Results for South Africa}

In South Africa, the findings of the MSM show that monetary policy has a significant impact on industrial production both in a recession and in a boom. The results of the analysis in Table 13 show that monetary policy instruments significantly impact industrial output in the country. As is shown in Table 14, the possibility of staying in regime 2 (expansion or boom) is higher than that of staying in regime 1 (recession).

Table 13. Regime Shifts in South Africa

\begin{tabular}{|l|r|r|r|r|}
\hline \multicolumn{1}{|c|}{ Variable } & Coefficient & Std. error & Z-Statistic & Prob. \\
\hline \multicolumn{5}{|c|}{ Regime 1 } \\
\hline IN & -2.4581 & 27.7589 & -8.8147 & 0.0000 \\
\hline MS & 0.0174 & 0.0003 & 57.2865 & 0.0000 \\
\hline C & 5.4891 & 5.1055 & 107.5020 & 0.0000 \\
\hline LOG(SIGMA) & 20.3196 & 0.0869 & 233.9690 & 0.0000 \\
\hline \multicolumn{5}{|c|}{ Regime 2 } \\
\hline IN & -2.4013 & 1.2169 & -1.9801 & 0.0477 \\
\hline MS & 0.0127 & 0.0006 & 20.6195 & 0.0000 \\
\hline C & 5.5018 & 1.7333 & 31.8856 & 0.0000 \\
\hline LOG(SIGMA) & 21.0641 & 0.0822 & 256.1212 & 0.0000 \\
\hline \multicolumn{5}{|c|}{ Transition Matrix Parameters } \\
\hline P11-C & 3.6312 & 0.5389 & 6.7388 & 0.0000 \\
\hline P21-C & -3.6651 & -5.8576 & 0.0000 \\
\hline
\end{tabular}

Source: author's computations using data from each country's Central Bank's statistical bulletins and Statistics Offices.

The likelihood of transitioning from a recession to an expansion is shown by the probability value of 0.0250 in regime $2_{(t)}$ as against that of 0.0258 in regime $2_{(t+2)}$. The economy is less 
likely to stay in regime 1 given that the probability value of 0.9750 in regime 2 is higher than that of 0.9742 in regime 1. This finding is in line with Baxter (2008) and Padayachee (2010) that revealed that South Africa weathered the 2008 global recession despite being a small, open economy.

Overall, the results show that the probability of staying in regime 2 (boom) is higher than that of staying in regime 1 (recession). In addition, the probability of shifting from regime 1 to regime 2 is high and the economy also lasts longer in a boom than in a recession.

Table 14. Transition probabilities in South Africa

\begin{tabular}{|c|c|c|}
\hline & Regime $1_{(t+1)}$ & Regime $2_{(t+2)}$ \\
\hline Regime $1_{(t)}$ & 0.9742 & 0.0258 \\
\hline Regime $2_{(t)}$ & 0.0250 & 0.9750 \\
\hline
\end{tabular}

Source: author's computations using data from each country's Central Bank's statistical bulletins and Statistics Offices.

Table 15. Constant expected durations

\begin{tabular}{|c|c|}
\hline Regime 1 & Regime 2 \\
\hline 10.7568 & 92.0587 \\
\hline
\end{tabular}

Source: author's computations using data from each country's Central Bank's statistical bulletins and Statistics Offices.

\section{Conclusion}

This paper examines the effects of changes in monetary policy in booms versus recessions on industrial output in each of the BRICS countries, determines the probability of moving from one regime to another, and estimates how long, on average, each regime will last. The findings reveal that the BRICS countries have similar business cycles. This finding is of interest because it suggests that in a large open economy like the BRICS group of countries, cyclical differences have not been an important factor in the quest to develop the bloc along areas of common interest. The study also finds evidence that monetary policy has significantly larger effects on industrial output in recessions than in booms. In addition, it is found that there is a high probability of moving from state 1 (recession) to state 2 (expansion) but a relatively low probability of moving from state 2 (expansion) to state 1 (recession) for all the countries. Finally, the study estimates how long, on average, each regime will last. It was found that, on average, the probabilities of staying in state 2 (boom) are higher than those of staying in 
a recession for all the five countries. The results for all the countries point to the fact that the probability of staying in a recession is less than that of staying in an expansion or boom. Owing to the number of distinctive characteristics of the BRICS economies, Kutu and Ngalawa (2016) reveal that the "BRICS countries are moving towards an inflation targeting/floating exchange rate system (similar monetary policy regime shifts); the adoption of countercyclical monetary and fiscal policies as against the previous procyclical or acyclical policies; are prone to the same external shocks due to the dominant influence of the US Dollar on their economies (Adler, Tovar Mora, 2012) and are EMEs with a per capita income lower than the average per capita income in the G7 countries (Calderón, Yeyati, 2009)". These distinctive characteristics are also consistent with the findings of this study, hence, may have informed their establishment of the BRICS' Development Bank as an alternative source of funds to the IMF and World Bank in their expedition to develop the bloc. Therefore, it can safely be recommended from the findings that the BRICS countries should sustain uniform policy consistency (monetary policy), especially as they formulate and implement economic policies to stimulate industrial output.

\section{Acknowledgements}

This work benefited from funding from the National Research Foundation (NRF) of South Africa and the University of KwaZulu-Natal's College of Law and Management Studies Research Office. We would like to thank them for the support received to present this paper at the Academic International Conference on Economics, Accounting \& Finance (AICEAF) at Cambridge University, United Kingdom, during which many useful discussions took place.

\section{References}

Adejare, A.T. (2014). Impact of Monetary Policy on Industrial Growth in Nigeria. International Journal of Academic Research in Business and Social Sciences, 1 (4), 18.

Adler, G., Tovar Mora, C.E. (2012). Riding Global Financial Waves: The Economic Impact of Global Financial Shocks on Emerging Market Economies. IMF Working Paper No. $12 / 188$.

Alvarez-Plata, P., Schrooten, M. (2006). The Argentinean Currency Crisis: A Markov-Switching Model Estimation. The Developing Economies, 1 (44), 79-91. 
Aradhna, A. (2014). GDP Growth and Manufacturing: Experience of BRICS Countries and Lessons to be learned by Central Asia. Wadhwani Foundation Policy Research Centre New Delhi Kazakhstan, Astana 1-2 July 2014.

Baxter, R. (2008). The global economic crisis and its impact on South Africa and the country's mining industry. Challenges for Monetary Policy - makers in Emerging Markets, 105.

Binici, M., Erol, H., Özlü, P., Ünalmış, D. (2013). Unconventional monetary policy tools and credit growth. Unpublished IMF Working Paper April 18, 2013.

Calderón, C., Levy-Yeyati, E.L. (2009). Zooming in: From aggregate volatility to income distribution. World Bank Policy Research Working Paper Series, No. 4895.

Caraiani, P. (2010). Modeling business cycles in the Romanian economy using the Markov switching approach. Romanian Journal of Economic Forecasting, 1, 130-136.

Casares, M. (2001). Business cycle and monetary policy analysis in a structural sticky - price model of the euro area. European Central Bank Working Paper No. 49, 1-43.

Chuliá, H., Guillén, M., Uribe, J.M. (2015). Measuring Uncertainty in the Stock Market. European Financial Management Association, 1-32.

Chun, K.H. (2014). The BRICs superpower challenge: foreign and security policy analysis. Ashgate Publishing, Ltd.

Clarida, R., Gali, J., Gertler, M. (2001). Optimal monetary policy in open versus closed economies: an integrated approach. The American Economic Review, 2 (91), 248-252.

Dedola, L., Lippi, F. (2000). The monetary transmission mechanism: evidence from the industries of five OECD countries. A CEPR Discussion Papers No. 2508.

Disyatat, P., Vongsinsirikul, P. (2003). Monetary policy and the transmission mechanism in Thailand. Journal of Asian Economics, 3 (14), 389-418.

Dolado, J.J., María-Dolores, R. (2001). An empirical study of the cyclical effects of monetary policy in Spain (1977-1997). Investigaciones Económicas, 1 (25), 3-30.

Elbourne, A., de Haan, J. (2006). Financial structure and monetary policy transmission in transition countries. Journal of Comparative Economics, 1 (34), 1-23.

Faia, E. (2008). Optimal monetary policy with credit augmented liquidity cycles. Unpublished manuscript, Goethe University Frankfurt, 1-13.

Fendoğlu, S. (2014). Optimal monetary policy rules, financial amplification, and uncertain business cycles. Journal of Economic Dynamics and Control, 46, 271-305.

Garcia, R., Schaller, H. (1995). Are the effects of monetary policy asymmetric? CIRANO Scientific Series, No. 95s-6.

Garcia, R., Schaller, H. (2002). Are the effects of monetary policy asymmetric? Economic Inquiry, 1 (40), 102-119.

Gonçalves, C.E.S., Salles, J.M. (2008). Inflation targeting in emerging economies: What do the data say? Journal of Development Economics, 1 (85), 312-318. 
Grimme, C. (2015). Essays on uncertainty and business cycles (pp. 1-157) (Doctoral dissertation, $\operatorname{lmu}$ ).

Hamilton, J.D. (1989). A new approach to the economic analysis of nonstationary time series and the business cycle. Econometrica: Journal of the Econometric Society, 357-384.

Harding, D., Pagan, A. (2002). Dissecting the cycle: a methodological investigation. Journal of monetary economics, 2 (49), 365-381.

Hardy, M.R. (2001). A regime-switching model of long-term stock returns. North American Actuarial Journal, 2 (5), 41-53.

Hawtrey, R.G. (1927). The Monetary Theory of the Trade Cycle and Its Statistical Test Cycle and Its Statistical Test. The Quarterly Journal of Economics, 471-486.

Hayo, B., Uhlenbrock, B. (2000). Industry effects of monetary policy in Germany. In: Regional aspects of monetary policy in Europe (pp. 127-158). Springer US.

Huber, F., Fischer, M.M. (2015). A Markov switching factor-augmented VAR model for analyzing US business cycles and monetary policy. Oesterreichische Nationalbank and Vienna University Department of Economics Working Paper No. 201.

Hutchison, M.M., Sengupta, R., Singh, N. (2013). Dove or Hawk? Characterizing monetary policy regime switches in India. Emerging Markets Review, 16, 183-202.

Iturriaga, F.J.L. (2000). More on the credit channel of monetary policy transmission: an international comparison. Applied Financial Economics, 4 (10), 423-434.

Kelly, R., O’Malley, T. (2014). A transitions-based model of default for Irish mortgages. Research Technical Paper 17RT14, Central Bank of Ireland.

Kim, S. (2003). Monetary policy rules and business cycles. The Scandinavian Journal of Economics, 2 (105), 221-245.

Korenok, O., Radchenko, S. (2004). Monetary Policy Effect on the Business Cycle Fluctuations: Output vs. Index Measures of the Cycle. EconWPA, Series (0409015).

Kutu, A.A., Ngalawa, H. (2016). Monetary Policy Shocks and Industrial Output in Brics Countries. SPOUDAI - Journal of Economics and Business, 3 (66), 3-24.

Lin, S., Ye, H. (2007). Does inflation targeting really make a difference? Evaluating the treatment effect of inflation targeting in seven industrial countries. Journal of Monetary Economics, 8 (54), 2521-2533.

Lin, S., Ye, H. (2009). Does inflation targeting make a difference in developing countries? Journal of Development Economics, 1 (89), 118-123.

Medhioub, I. (2015). A Markov switching three regime model of Tunisian business cycle. American Journal of Economics, 3 (5), 394-403.

Mishkin, F.S. (1995). Symposium on the Monetary Transmission Mechanism. The Journal of Economic Perspectives, 3-10. 
Naudé, W., Szirmai, A., Lavopa, A. (2013) Industrialization lessons from BRICS: A comparative analysis. SSRN Discussion Paper No. 7543.

Ngalawa, H., Viegi, N. (2011). Dynamic effects of monetary policy shocks in Malawi. South African Journal of Economics, 3 (79), 224-250.

Padayachee, V. (2010). Global economic recession: effects and implications for South Africa at a time of political challenges. Claves de la Economia Mundial, 1-20.

Peersman, G., Smets, F. (2001). Are the effects of monetary policy in the euro area greater in recessions than in booms? ECB Working Paper No. 52, 1-29.

Peersman, G., Smets, F. (2005). The industry effects of monetary policy in the euro area. The Economic Journal, 115 (503), 319-342.

Rose, A.K. (2007). A stable international monetary system emerges: Inflation targeting is Bretton Woods, reversed. Journal of International Money and Finance, 5 (26), 663-681.

Schaller, H., Norden, S.V. (1997). Regime switching in stock market returns. Applied Financial Economics, 2 (7), 177-191.

Schularick, M., Taylor, A.M. (2012). Credit booms gone bust: monetary policy, leverage cycles, and financial crises, 1870-2008. The American Economic Review, 2 (102), 1029-1061.

Sims, C.A., Zha, T. (2006). Were there regime switches in US monetary policy? The American Economic Review, 1 (96), 54-81.

Taylor, J.B. (1993, December). Discretion versus policy rules in practice. In: Carnegie-Rochester conference series on public policy, Vol. 39 (pp. 195-214). North-Holland.

Tenreyro, S., Thwaites, G. (2015). Pushing on a string: US monetary policy is less powerful in recessions. CEPR Discussion Paper No. DP10786.

Zhensheng, Z.Y.J. (2002). Monetary Channel, Credit Channel and the Effectiveness of Monetary Policy. Journal of Finance, 9, 003. 